\title{
Die ampte in die huidige tydsgewrig met die oog op groter differensiasie
}

\author{
M J du P BEUKES
}

Sedert die verskyning van Berkhof se "Wat is er aan de hand met het ambt", ' het die diskussie rondom die ampte in intensiteit toegeneem. ${ }^{2}$ Sedert 1970 staan die differensiasie van die ampte op die sakelys van die Nederduitsch Hervormde Kerk van Afrika. ${ }^{3}$ Bewustelik of onbewustelik is hierdie moeilike onderwerp tot vandag toe agterweë gelaat. Die omvang van hierdie studie is wyd. Die inhoud van hierdie onderafdeling sal daarom slegs enkele inleidende opmerkings wees met die oog op verdere diskussie in die toekoms. Die inhoud hiervan sal getuig van 'n studieresultaat in stryd met die tradisionele opvattings, maar wat volgens skrywer gegrond is op die Skrif, en tóg inpas in die kader van die reformatoriese beskouings met betrekking tot die ampte. Vanweë die wye omvang van die onderwerp is slegs enkele Nuwe Testamentiese en reformatoriese gegewens na vore gebring.

Differensiasie van die ampte sal alleen moontlik wees as so 'n differensiasie nie in stryd is met die Skrif nie. Of daar in die Skrif sondermeer sprake is van ampte, soos ons dit vandag ken, kan nie sondermeer bepaal word nie.

E Käsemann, Heinrich Schlier, Eduard Schweizer, en Hans Freiherr von Campenhausen is van oordeel dat daar in die Nuwe Testament geen sprake van ampte is nie. Die hele gemeentestruktuur word gesien as 'n "ordnung vom Charisma aus." Die charismatiese is volgens hulle die enigste funksie wat in die gemeente bestaan het. Die charismatiese word opgevolg deur 'n tweede periode, ná-NuweTestamenties, waar die institusionele op die voorgrond kom. Hierdie institusionele periode noem hulle die "Frühkatolizismus". Alles wat in die Nuwe Testament lyk na institusionele, word deur hulle beskryf as 'n truprojeksie vanuit die "Frühkatolizismus" deur 'n skrywer wat in die tweede generasie gemeente sou geleef het. Hierdie redenasie lei tot 'n verwerping van die hele "ampsteologie" as onPaulinies, on-Lukanies en selfs on-Skriftuurlik. ${ }^{4}$ Käsemann en ander bou hulle hele redenasie hoofsaaklik op die feit dat charisma en amp teenoor mekaar staan en dat elkeen beperk is tot ' $n$ bepaalde periode. Resente studies het egter aan die lig gebring dat amp en charisma nie mekaar uitsluit nie maar insluit. Amp sonder 'n bepaalde charisma is duidelik in stryd met die Nuwe Testament. Die amp is self 'n charisma. ${ }^{5}$ 
Waar enersyds beweer word dat die ampte of selfs die prinsipe van die ampte nie in die Nuwe Testament voorkom nie, word andersyds geoordeel dat die ampte soos ons hulle vandag in die kerk het, sondermeer 'n Nuwe Testamentiese gegewene en daarmee 'n klaar omlynde goddelike opdrag is. Die Nederlandse Geloofsbelydenis verklaar dat die ware kerk geregeer moet word volgens die geestelike regering wat God ons in sy Woord geleer het. ${ }^{6}$ In die bevestigingsformulier vir redikante word die gemeente opgeroep om te luister na 'n kort uiteensetting van die instelling en die amp van herders of dienaars van die Woord. Hierdie uiteensetting is volgens die formulier 'n "uiteensetting uit die Woord van God."7 Dieselfde oproep kom wanneer daar gespreek word oor die instelling van die amp van ouderlinge en diakens. ${ }^{8}$ Uit die verskillende formuliere kan die afleiding gemaak word dat die amp van ouderling, dienaar van die Woord en diaken juis op een bepaalde wyse in die Nuwe Testament beveel word en dat hulle volle opdrag wat draagwydte en grense betref ten volle beskryf word. Ons belydenisgeskrifte en formuliere is die produk van die reformatoriese teologie. Die kerkregtelike ordening van die reformatoriese kerke in die sestiende eeu is volgens Polman vir die reformatore 'n "ius divinum".

In Luther se Würtemberger kerkorde van 1536 lees ons: "Daar de heilige apostel Paulus niet ongegrond zo nadrukkelijk bevolen heeft, dat het ordelijk en behoorlijk in de kerk moet toegaan, hebben wij de volgende kerkorde, naar de regel der godelijke Schrift, gesteld en ingericht." 10 Die begrip goddelike reg kom volgens Polman by Luther meer as honderd keer voor. Die drie ampte soos beskryf in die Nederlandse Geloofsbelydenis is volgens Polman vir Calvijn ook gegrond op 'n "ius divinum". Dat die amp as sodanig en die sterk grense tussen die drie of vier ampte in die besonder nie vir die reformatore sondermeer 'n Nuwe Testamentiese gegewene is wat gehanteer moet word as 'n goddelike gebod nie, is uit verskillende oogpunte duidelik: As die kerkregering volgens 'n bepaalde vorm vir Luther 'n "ius divinum" was, sou hy hierdie saak nie sondermeer in die hande van die wêreldlike owerheid gelaat het nie. Calvijn se uitgangspunt met betrekking tot die ampte is Efesiërs 4:11. Hy oordeel dat sommige ampte soos die van die "euangelistai" net gegee is vir die grondlegging van die kerk - God kan hulle weer later gee as dit nodig sou wees. ${ }^{11}$ Selfs met betrekking tot die diakenamp oordeel hy dat dit 'n funksie is wat aan die "tijd gebonden is, en dus niet permanent". ${ }^{12}$ Dat die ampte as sodanig en die afsonderlike ampte in die Nuwe Testament skerp afgegrens sou wees, kan nie sondermeer aanvaar word as die algemene opvatting van die reformatore nie. Opvallend is dat die verskillende sinodebesluite uit die sestiende eeu die drie of vier ampte nie sondermeer beskryf as van goddelike oosprong en alleen geldend vir alle tye nie. ${ }^{13}$ As die Nederlandse 
Geloofsbelydenis en die bevestigingsformuliere die drie ampte beskryf as deur God gegee kan nie sondermeer daaruit afgelei word dat die beginsel en funksionering van die ampte tot in die fynste besonderhede deur die Skrif beveel en uitgewerk word nie. In die Nuwe Testament kan ons sê, word hoogstens geleer van ampte "incipient". ${ }^{14}$ In prinsipe kom die saak van die ampte duidelik na vore sonder dat die ampte streng in vaste vorme beskryf word. In die Nuwe Testament gaan dit eerder om "diakonia" oor 'n wye linie as om ampte in 'n enkel vasgevangde vorm. ${ }^{15}$

Hierdie "diakonia" verrig Jesus Christus self met sy Gees. ${ }^{16} \mathrm{Hy}$ wil egter mense gebruik om hierdie "diakonia" te verrig. ${ }^{17}$ Volgens Alan Richardson kan die "diakonia" wat in die Nuwe Testament voorkom, altyd in drie groot groepe ingedeel word naamlik die verkondiging, die opsig en die barmhartigheidsdiens. ${ }^{18}$ Hierdie opvatting is myns insiens Nuwe Testamenties korrek en pas nog steeds in by die kader van ons reformatoriese opvattings, of sal ons liewer sê die reformatoriese ampsbeskouing weerspreek nie hierdie opvatting nie.

Die vrae onder bespreking sal gevolglik sentreer rondom die volgende: Is daar in die Nuwe Testament sprake van 'n differensiasie met betrekking tot die "diakonia" wat beskrywend is vir die verkondiging, die opsig en die barmhartigheidsdiens? Die gegewens wat hier na vore gebring word, kan vanweë die wye omvang slegs sentreer rondom enkele sentrale aspekte.

Aanvanklik tref ons in die Nuwe Testament naas die apostels geen ander funksies aan nie. ${ }^{19}$ Die volle omvang van die kerk se werk is deur die apostels gedoen. ${ }^{20}$ Differensiasie binne een "amp" in die wydste sin van die Woordverkondiging, opsig en barmhartigheidsdiens is deur hulle verrig terwyl hulle tegelyk gefunksioneer het as die oog- en oorgetuies van die opgestane "Kurios".

Die groei van die gemeente in Jerusalem het tot gevolg dat die apostels nie meer al die dienswerk in die gemeente kon doen nie. Die verwaarlosing van die Helleense weduwees het gelei tot die verkiesing van die "sewe" in Handelinge 6 ter wille van die daaglikse "diakonia". Tradisioneel word aanvaar dat ons hier te doen het met die instelling van die diakenamp. ${ }^{21} \mathrm{G}$ Stählin beskou die manne met hulle Griekse name as die "Führungsgruppe des hellenistischen Gemeindeteils". ${ }^{22}$ Redelike sterk argumente word aangevoer dat ons hier eerder met die instelling van die ouderlingsamp as die diakensamp te doen het. ${ }^{23}$ Die broeders wat in Handelinge 6 gekies word, word in Handelinge 21:8 "hoi heptai" genoem. Hierdie benaming laat sterk dink aan die oudstes van die Joodse sinagoge..$^{24}$ Net soos die oudstes van die Joodse sinagoge moet hulle manne wees vol van die Heilige Gees en van wysheid. ${ }^{25}$ Van Ginkel oordeel dat ons hier te doen het met 'n "diakonia" ter wille van 'n deel van die gemeente. Die diakonia wat hierdie sewe moes verrig, is wyd gedifferensieerd. 
Die sewe kan gesien word as ' $n$ gespesialiseerde groep ter wille van 'n deel van die gemeente. Binne hierdie deel het hulle 'n wyd omskrewe "diakonia": Die versorging van die weduwees, die stoflike gemeenskap van die gelowiges, die eenheid en gemeenskap van die gemeente, die viering van die heilige nagmaal en selfs die verkondiging van die Woord skyn nie uitgesluit te wees uit hulle werk nie. ${ }^{26}$ Hierdie "diakonia" bevat elemente van al drie die ampte soos ons hulle vandag ken.

In die boek Handelinge maak die "presbuteroi" onverwags hulle verskyning. Hulle "diakonia" strek oor 'n breë linie. Hulle ontvang die offergawes wat Paulus en Barnabas ingesamel het, ${ }^{27}$ hulle hou as 'n liggaam opsig oor die werk van Paulus en Barnabas, ${ }^{28}$ saam met die apostels neem hulle besluite wat geldend is vir die hele kerk. ${ }^{29}$ Die differensiasie binne die korps van "presbuteroi" te Jerusalem loop nog breër. Sonder enige inleiding of toeligting word die "presbuteroi" in Jakobus 5:14 ten tonele gevoer as 'n "diakonia" wat in die besonder gerig is op die siekepastoraat. In Petrus se eerste brief word aan die "presbuteroi" opgedra om die kudde van Christus te "poimainein". ${ }^{30}$ Hulle het 'n herderlike taak, sonder dat presies gesê word wat dit inhou: "In ieder geval zal het beteken, dat zy de gemeente bijeen moeten houden en moeten bewaren bij het geloof in de Heer die de opperherder is. ${ }^{31}$ Hulle word gewaarsku teen winssug; "hetgeen er op wijst, dat zij de gemeentekas onder hun beheer hebben en ook recint hebben op een uitkering daaruit." ${ }^{32}$ Verder moet hulle geen heerskappy voer nie "hetgeen wijst op verregaande bevoegdheden, wellicht met name op het gebied van de tucht." Petrus noem homself 'n "sumpresbuteros". ${ }^{34}$ Hiermee stel hy homself naas die "presbuteroi" en hulle naas hom. Dit sal daarom seker nie 'n verregaande afleiding wees nie om te beweer dat hierdie "presbuteroi" net soos Petrus ook die reg en die voorreg van Woordverkondiging gehad het.

In Handelinge 20:17 en 28 beskryf Lukas die ouderlinge van 'n Pauliniese gemeente. Dit is opvallend dat die "presbuteroi" van vers 17 deur Paulus "episkopoi" genoem word. Lukas gebruik deurgaans die woord "presbuteros", maar wanneer hy Paulus self aan die woord stel, gebruik hy die woord "episkopos". Hieruit word geoordeel dat hier spraakgebruik van twee bestaande modelle sonder onderskeid ingevoer word. Volgens Haenchen is dit die model van die Joodse sinagoge en die model van die Qunrangemeenskap, ${ }^{35}$ volgens Lekkerkerker die model van die Jonds-Christelike gemeenskap wanneer die benaming "presbuteros" gebruik word en die model van die Griekse beskawing wanneer die begrip "episkopos" gebruik word. In die Hellenistiese gemeentes sou die leidinggewende figure van die gemeente bekend gestaan het as "episkopoi" en in die Joodse gemeentes "presbuteroi". ${ }^{36} \mathrm{JH}$ Roberts het egter oortuigend aange- 
toon dat die "presbuteroi" en die "episkopoi" nie twee verskillende "diakoniai" in die Nuwe Testament aandui nie, maar slegs sinonieme is vir een funksie. ${ }^{37}$ Die besondere "diakonia" van die "presbuteros"/ "episkopos" word in vers 28 omskryf as "prosechete heautous" en "poimainein tén ekklesian". Kommentare is dit eens dat hier in die besonder gewys word op die opsig van die ouderlinge oor hulleself en oor die hele kudde. ${ }^{38}$ Voordat Paulus aan die "presbuteroi"/"episkopoi" hulle amptelike taak opdra, beskryf hy eers sy eie werk te Efese. Hy het alles wat nodig is met die oog op hulle saligheid in die openbaar en van huis tot huis aan hulle verkondig en hulle daarin onderrig. ${ }^{39}$

Paulus hou hier sy eie werk aan die "presbuteroi"/"episkopoi" voor as model waarvolgens hulle in die gemeente moet funksioneer. Die "diakonia" van die "presbuteroi"/"episkopoi" van Handelinge 20 het daarin bestaan dat aan hulle "de geestelijke leiding der gemeente wordt opgedragen. $\mathrm{Zij}$ moeten deze van de apostel overnemen en de gemeente bewaren bij de apostolische leer, zoals herders hun kudde bewaren. Dwalingen moeten zij onderkennen en uitzuiveren, de zwakken moeten zij met speciale zorg omringen, hetgeen duidt op de zorg voor de armen. ${ }^{\prime 40}$

Waar die "presbuteroi"/"episkopoi" met hulle wyd gedifferensieerde opdrag in Handelinge, Jakobus en Petrus sterk voor die dag tree, verdwyn hulle op die agtergrond in die gemeentelike briewe van Paulus. In die gemeentelike briewe, wat waarskynlik voor Handelinge en die ander genoemde briewe geskryf is, tree besondere "charisma" sonder dat dit verbind word aan 'n bepaalde funksionerende groep, sterk op die voorgrond. Naas die wye linie charisma wat vermeld word in Romeine 12 en 1 Korintiërs 14, word in Efesiërs 4:11 ook nog verwys na apostels, profete, evangeliste, herders en leraars. Die apostels, profete en evangeliste beskryf Calvyn as ampte wat hoofsaaklik gefunksioneer het tydens die grondlegging van die kerk vanweë die besondere situasie. ${ }^{41}$ Die "poimenes" en "didaskaloi" beskryf hy as funksies wat permanent geldend is in die kerk. Hierdie "pastors" en "teachers" omskryf hy as behorende tot dieselfde "class". Dit wil sê die "pastor" is tegelyk ook "didaskolos" en die "didaskolos" tegelyk ook "pastor". Tog wil Calvyn wanneer dit kom by die funksionering, hierdie twee funksies duidelik onderskei." (Die ontbreking van die lidwoord tussen "poimenas" en "didaskalous" is volgens Fritz Rienecker nie voldoende rede om te aanvaar dat ons hier te doen het met een funksie wat twee "diakonia" verrig het nie. Die "poimenes" is tegelyk herders, leraars en opsighouers. Die leraars se diakonia is slegs beperk tot die leeraktiwiteit. $^{43}$

Wanneer die pastorale briewe geskryf word, vertoon die organisasie van die Pauliniese gemeente die beeld van die Joods-Christelike. 
Daar is sprake van "presbuteroi" en "episkopoi". Uit 1 Timoteus 5:17 blyk dat daar differensiasie aangebring is op grond van die verskillende funksies wat uitgeoefen is. Volgens die bevestigingsformulier vir ouderlinge het ons hier te doen met twee groepe ouderlinge. "Het gaat hier om een ambt, alleen de dragers ervan vervullen verschillende functies." ${ }^{\mathbf{4 6}}$

Uit die verband is dit hoegenaamd nie duidelik of ons hier te doen het met twee afsonderlike groepe of net een groep met verskillende funksies nie. ${ }^{47}$

Almal wat egter op hierdie besondere wyse in die kerk besig was, het 'n "times" ontvang. ${ }^{48}$ Die "presbuteros"/"episkopos" van die pastorale briewe moes regeer ${ }^{49}$, vir die gemeente sorg, ${ }^{50}$ vermaan ${ }^{51}$ en arbei in Woord en leer ${ }^{52}$. Hy was belas met bediening van die Woord, opsig en finansieel-administratiewe werk.

Die "episkopoi"/"presbuteroi" figure het in die eerste Christelike gemeentes gefunksioneer as leidinggewende figure met 'n wyd gedifferensieerde diakonia. Skerp lyne is nie getrek en gehandhaaf tussen Woordbediening en opsig nie. Vanweë tydsbestek kan ons met betrekking tot die verkondiging net konstateer dat dit ook gefunksioneer het op 'n gedifferensieerde wyse. Dit het bestaan uit binnemeentelike en buitegemeentelike verkondiging, ${ }^{53}$ - evangelisasie, prediking, pastoraat, kategese en baie ander gestaltes wat waarskynlik net vir die eerste periode van die kerk besondere betekenis gehad het en dikwels deur die apostels nie hoog aangeslaan is nie. ${ }^{54}$

Met betrekking tot die barmhartigheidsdiens kan nie sondermeer uitgemaak word of dit in die eerste Christelike gemeentes bestaan het as 'n vaste geordende amp nie. Bronkhorst oordeel dat daar aanvanklik net een amp of "diakonia" in die kerk was, naamlik die van die "episkopos"/"presbuteros". Uit hierdie een het later die verskillende ampte, ook die van die diaken, voortgevloei. ${ }^{55}$ Uit die pastorale briewe is dit egter duidelik dat die "diakonoi" waarskynlik naas die "presbuteroi"/"episkopoi" gefunksioneer het as 'n selfstandige groep. ${ }^{56}$ Indien ons aanvaar dat die begrip "diakonia" in die Nuwe Testament dui op al die dienswerk van die kerk, ${ }^{57}$ moet ons konkludeer dat die differensiasie in die eerste Christelike gemeentes baie wyd was. Sien ons die begrip "diakonos" wel as 'n vaste geïnstitueerde amp, het die differensiasie met betrekking tot hierdie funksie hoofsaaklik bestaan uit 'n groep wat uitdeel in die wydste sin van die woord en 'n groep wat insamel. ${ }^{58}$

Samevattend kan ons sê: Die Nuwe Testament trek nie skerp lyne tussen die verskillende "diakoniai" wat in die kerk tot uitvoer gebring moet word nie. Die beginsel van differensiasie is meer aanwesig as afwesig.

In hierdie studie moet ons ons ook noodwendig besighou met die vraag of die "diakonia" van die kerk alleen bedoel is vir die gestalte 
van die man en of daar in die Nuwe Testament nie ook ruimte gelaat word met betrekking tot differensiasie na die verskillende geslagte nie. Hier sal ons ook net enkele riglyne kan trek.

Aangesien die hele Nuwe Testament in die lig van die Christusgebeure nie besondere dienswerk vir die vrou in die kerk uitsluit nie maar juis insluit, lyk dit geregverdig om in hierdie studie hoofsaaklik te let op die teksverse wat gewoonlik gebruik word as teenargument waarom die vrou nie tot die ampte toegelaat mag word nie. Aangesien die Nederduitsch Hervormde Kerk van Afrika reeds besluit het om die vrou toe te laat tot die diakenamp, ${ }^{59}$ sal ons nie verder hierop ingaan nie.

Volgens 1 Korintiërs 14:34 word die vrou nie toegelaat om in die gemeente te "lalein" nie. Hulle moet swyg en onderdanig wees. Sommige kommentare oordeel sondermeer dat die vrou hier verbied word om in die gemeente te praat, en pas die praat dan ook toe op die verkondiging. Grosheide sê net soos in 11:5 het ons hier te doen met "profèteuein." In 11:5 sê hy is egter nie sprake van "en tais ekklesiais" nie. Hy kom tot die gevolgtrekking: Die vrou mag wel "profèteuein" maar nie in die "tais ekklesiais" nie. ${ }^{60}$ Hierdie verbod, sê Grosheide, is absoluut. God het dit vir alle plekke en alle tye ingestel. F Davidson oordeel: die vrouens word hier verbied om te profeteer aangesien dit in stryd is met die algemene gebruik van die kerk. In 11:5 is dit toegelaat met die oog op "smaller and more informal meetings such as the prayer meeting which took place in the house of Mark's mother. ${ }^{61}$ Na deeglike studie kom prof G M M Pelser op goeie gronde tot die gevolgtrekking dat 1 Korintiërs 14:34 en 35 on-Paulinies is. Pelser voer die volgende argumente aan: "en pasais tais ekklesias" in 33(b) en "en tais ekklesiais" in 34(a) is in direkte konflik met mekaar. Die verbod om te swyg in die besonder vir vrouens skyn vreemd te wees in die konteks van die hele hoofstuk 14. Die uitspraak dat die vrou moet swyg in die erediens sou in stryd wees met die héle Pauliniese opvatting in verband met die vrou (vergelyk 3:28) ${ }^{62}$ Gesaghebbende kommentare soos Hilgenfeld, Holstein, Michelsen, Baljon, Schmiddel en Weisz praat dieselfde taal in hierdie verband as prof Pelser. ${ }^{63}$ Heinz Wendland wil 14:34 handhaaf as Paulinies maar nie daaruit die verbod om te verkondig aflei nie. "Hier ist gar kein geistgewirktes sprechen der Frauen verboten." ${ }^{\prime 64}$ Volgens Pop word die gereelde "onder onsies" wat die vrouens met hulle mans gehad het, hier verbied. ${ }^{65}$ Groenewald roep ons op om die "Zits im leben" waarom dit hier gaan, raak te sien. ${ }^{66}$ Dit gaan hier in die besonder om die orde in die gemeente. Die voorreg om in die gemeente te bid of te profeteer word haar nie ontsê nie. As Paulus die vrou in die gemeente verbied om te spreek, "dan heeft dit betrekking op het deelnemen aan de discussie, het verlangen van verklaringen, het uiten van critiek en het stellen van 
vragen: dit moeten ze thuis maar aan haar eigen mannen doen." ${ }^{67}$

Indien 14:34 Paulinies sou wees en dit hier in die besonder daarom sou gaan om die vrou te verbied om in die gemeente te "profèteuein", sou hierdie teks in direkte teenstelling met 11:5 wees. In 11:5 word melding gemaak van die vrou wat in die erediens "proseuchomein" en "profèteuein". Die moontlikheid om in die erediens te bid en te profeteer, word afgewys met die stellings: hier is nie sprake van verkondiging nie maar van momentele ekstase, ${ }^{68} 11: 5$ speel af buite die gemeentelike erediens. ${ }^{69}$ Uit die verband is dit juis duidelik dat die gebeure in 11:5 afspeel in die erediens. Geen enkele rede kan gegee word waarom "profèteuein" juis hier die betekenis van momentele ektasie sou hê nie. In 11:5 maak Paulus die stelling in verband met die vrou se profesie en gebed op so 'n wyse dat dit dien as beskrywend van wat normaalweg in 'n erediens plaasgevind het. Pelser kom tot die gevolgtrekking: 1 Cor 11:5 bears witness not only of women who were endowed with the gift of prophesy, but also of the public exercising of this gift in public worship. ${ }^{20}$ In die eksegese van 11:5 is daar niks wat die vrou verbied om die amp te beklee nie.

In 1 Timoteus 2:8-15 word die vrou opgeroep om haar in stilte te laat leer in alle onderdanigheid. Die vrou word nie toegelaat om onderrig te gee of oor die man te heers nie. Calvyn het veral hierdie teksvers gebruik om die vrou uit te sluit uit die amp van bedienaar van die Woord en om haar alle regering in die kerk te ontsê. As die vrou toegelaat word om te onderrig, sal die goeie orde in die skepping verbreek word, want God het die onderrig aan mans alleen opgedra. Die voorbeeld van Debora as regeerder in die Ou Testament is uitsondering op die reël. Die uitsondering kan nie gebruik word as voorbeeld om die ongebruikte te verhef tot reël nie. ${ }^{71}$ As die vrou in die kerk heers, sal dit in stryd wees met haar wese as vrou, ${ }^{72}$ in stryd met die plek wat God aan haar toegesê het. ${ }^{73}$ Ter wille van haarself en ter wille van die kerk is so 'n "unholy tampering with divine authority forbidden. "74 Die vrou se geneem wees uit die man, haar onderdanigheid, is nie deur Christus opgehef nie. Die man is die hoof van die vrou en Christus is die hoof van die man. Hierdie orde moet ook weerspieël word in die kerk. ${ }^{75}$ Die Interpreter's Bible het veral besondere aandag gegee aan die vrou in regerende hoedanigheid in die gemeente. Die "authentein" (vers 12) wil hy nie vertaal met "heers oor" nie, maar met "interrupt" ${ }^{76}$ Pelser is van oordeel dat die sentrale in hierdie perikoop nie een of ander saak met betrekking tot die erediens is nie, maar die alledaagse verhouding van die man tot sy eie vrou. Op goeie gronde oordeel hy "that the command to silence in 1 Tim 2:11 cannot be accepted as Pauline". "Taking Paul's view as a whole, the impression is rather that this command to silence reflects a post-Pauline development or otherwise just represents the approach of a certain group in the early church. "77 As ons 
besondere aandag gee aan die besondere situasie waarbinne 1 Timoteus 2:8-15 afspeel, is dit veral uit vers 13,14 en 15 duidelik dat dit nie hier gaan om die vrou se optrede in die erediens nie, maar om die vrou se optrede binne die huwelik.

Die grootste beswaar waarteen gestuit word met betrekking tot die toelating van die vrou as ouderling en bedienaar van die Woord, is die diskussie rondom die heerskappy wat die man oor die vrou moet voer. Van heerskappy in juridiese sin is daar egter in die kerk nie sprake nie; slegs van 'n "Christokratie". Die reg van die kerk, oordeel Parth, is 'n Evangelium verkundigendendes Recht. ${ }^{78}$ Die kerk het net een Heer, naamlik Jesus Christus. Deur Hom is alle heerskappy absoluut en radikaal uitgesluit. ${ }^{79}$ Die ouderlinge word juis opgeroep om nie opsig te hou as heersers (Katakurieuontes) oor die kudde nie, maar as ' $n$ voorbeeld.$^{80}$ Dit is opvallend dat die LXX die Hebreeuse mšl van Genesis 3:16 vertaal met "kurieuein", wat juis die ouderlinge in 1 Petrus 5:3 verbied word. Is dit nie miskien 'n positiewe aanduiding dat die man se heers oor sy vrou van 'n geheel-en-al ander orde is as die heerskappy van die ampsdraers in die kerk nie? Wil Petrus nie miskien in 1 Petrus 5:3 vir die ouderlinge sê: julle moet nie in die gemeente heers soos in die huwelik nie? Om die regering in die kerk te beskryf, maak die Nuwe Testament veral van die volgende begrippe gebruik: poistémi ${ }^{81}$ kubernésis, ${ }^{82}$ hégoumenos, ${ }^{83}$, poimén ${ }^{84}$, en episkopos ${ }^{85}$. Uit die ontleding van hierdie begrippe is dit duidelik dat die regering in die kerk van 'n geheel-en-al ander orde is as dié in die alledaagse gang van sake. In die kerk moet ons eerder praat van leiding gee as van heerskappy voer. Die regering of die leiding van die ampsdraers in die kerk is meer gerig op geestelike leiding as op juridiese mag. "Wanneer de vrouw hiervoor charismata blijk te bezitten, dan is er bijbels gezien, geen enkel geldig argument om haar geen plaats in de leiding van kerk en gemeente te geven. De kerk zal zichzelf iets noodzakelijks en waardevols onthouden, wanneer zij het niet doet." ${ }^{186}$

Gedurende die laaste aantal jare is die behoefte al hoe meer gevoel dat daar 'n groter differensiasie met betrekking tot die ampte moet kom. Die voorstelle tot vernuwing het hoofsaaklik gesentreer rondom die amp van die ouderling.

$R$ Boon ${ }^{87}$ waardeer die ouderlingsamp baie laag. Dit is nie ' $n$ amp wat deur Christus ingestel is nie, maar slegs 'n konkretisering van die algemene priesterskap van die gelowiges. Volgens hom is alleen die bedienaar van die Woord ampsdraer in die volle sin van die woord. Al die funksies van die huidige predikant en ouderling kan in die een persoon van die dienaar van die Woord verteenwoordig word. Die ouderlinge kan nog fungeer, maar dan hoogstens as assistente vir die bedienaars van die Woord. Hierdie beskouing van Boon lei ongetwyfeld in die rigting van die Roomse episkopale sisteem. 
Hierdie voorstelle van Boon wyk egter soseer af van die presbiteriale tradisie, dat dit van daaruit besien alleen maar verlies en agteruitgang beteken. Dit sluit ook nie aan by die beweging van die maatskappy van ons dag nie, "die niet gaat in de richting van een monarchale structuur, maar van democratisering" ${ }^{\prime 88}$

$\mathrm{H} \mathrm{d}^{\prime}$ Espiné ${ }^{89}$ wil nie die amp van ouderling ophef nie, maar verhef tot die enigste amp in die kerk.

Al die "diakonia" in die gemeente moet verrig word deur 'n kollege van presbiters. Hy besef dit sal nie maklik wees om sy voorstelle te realiseer nie. Hy stel voor dat die kerkorde bloot so gewysig word dat al die dienaars van die Woord ouderlinge word en die ouderlinge ten volle deel kry aan die bediening van die Woord en sakramente. Al die regte en voorregte wat voorheen alleen vir die dienaars van die Woord gegeld het, word nou ook die reg en voorreg van al die ampsdraers van die kerk.

Berkhof ${ }^{90}$ pleit vir 'n terugkeer na die visie van die Nuwe Testament. In die gemeente moet net een amp, naamlik diè van oudste, bestaan. Binne hierdie algemene amp moet differensiasie plaasvind volgens die behoefte van die gemeente en volgens die "charismata" wat aan daardie besondere gemeente se lidmate geskenk is. Hy onderskei binne die amp van die oudste die dienaar van die Woord, die leraar, die herder en diaken. Die differensiasie loop nog verder. Hierdie onderskeie onderafdelings van die een amp kan bestaan uit gespesialiseerde en nie-gespesialiseerde ampsdraers, uit gesalarieerde en nie-gesalarieerde ampsdraers.

$G$ van Ginkel ${ }^{91}$ wys elke vorm van verabsolutering van die ampte af as in stryd met die Nuwe Testamentiese bedoeling. Die feit dat feitlik elke Nuwe Testamentiese boek en brief ander gegewens na vore laat kom, is vir hom die bewys dat elke nuwe tyd nuwe vorme vra. Gesien vanuit die Nuwe Testamentiese scopus wil hy die amp van ouderling weer verhef tot amp in die volle sin van die woord. Vanweë die moderne situasie wil hy dat daar wye differensiasie sal plaasvind binne hierdie een amp. Hy laat val veral die klem baie sterk op spesialisasie. Met die oog op spesialisasie moet 'n deel van die oudstes opleiding ontvang. Die gemeente moet geregeer word rondom die gemeentelede se sosiale, kulturele en godsdienstige belangstelling. Elkeen van hierdie groepe kry dan 'n oudste wat opgelei word in 'n bepaalde rigting om goed aan te pas by sy besondere groep. Hierdie opgeleide oudste van die groep besit al die regte en voorregte van die huidige dienaar van die Woord. Hy word bygestaan deur oudstes wat nie noodwendig almal 'n besondere opleiding ontvang het nie. Binne ' $n$ bepaalde groep word 'n bepaalde persoon se "charismata" opgemerk, hy word deur hulle en nie deur die gemeente gekies as oudste nie. Net soos die ten volle gespesialiseerde oudstes ontvang die res ook honorering. Afvaardiging na die 
meerdere vergaderings word nie gekies uit die kerkraad nie, maar uit die verskillende groepe. Die terminering met betrekking tot die ouderlingsamp word opgehef. Die amp van dienaar van die Woord bly nog bestaan maar dan hoofsaaklik as deskundige teoloog wat tot beskikking is van al die groepe in die gemeente.

Hoewel die Nuwe Testament nie skerp lyne trek tussen die verskillende "diakoniai" van die kerk nie, lyk dit tog geregverdig om die volgende stelling te maak: Uit die Nuwe Testamentiese gegewens is dit duidelik dat dit God welbehaaglik is dat die bediening van die Woord (sigbaar en onsigbaar), die opsig en die barmhartigheidsdiens sentraal sal staan in die kerk se "diakonia" en dat hierdie werk gedoen sal word deur besondere persone wat daarvoor geroep is. Hoewel ander kerkordes miskien ook uit die Nuwe Testament afgelei kan word, is die huidige funksionerende in ons Kerk nie in stryd met die Skrifgegewens nie en is dit juis die pad wat die reformatoriese kerkreg bewandel het. In hierdie lig behoort differensiasie in ons Kerk hoofsaaklik plaas te vind binne die breë lyne van die tans bestaande kerkreg.

Om Christus se opdrag aan die kerk te vervul en om in die verskeidenheid van dienste te voorsien is daar in die Nederduitsch Hervormde Kerk van Afrika drie ampte: die dienaars van die Woord, die ouderlinge en die diakens. ${ }^{92}$ Die dienaars van die Woord word onderskei in die herders en leraars - dit is die predikante en die hoogleraars en leraars in die godgeleerdheid - dit is die professore en ander dosente in die teologie. ${ }^{93}$ In die Kerkwet Artikel 5,3 word die dienswerk van die dienaars van die Woord volledig beskryf sonder dat diè van die hoogleraars en ander dosente in die teologie onderskei word. Indirek word hier gesê dat die hoogleraars en ander dosente in die teologie dieselfde dienswerk as die herders en leraars mag verrig. Hierdie stelling word bevestig in Bepaling $163 .{ }^{94}$ In Bepaling 78 word die dienswerk van die professore en ander dosente in die teologie noukeurig omskryf. ${ }^{95}$ Hierdie "diakonia" sentreer hoofsaaklik rondom die opleiding van toekomstige bedienaars van die Woord. Dit is ook hulle taak om kerk en volk met advies en leiding te dien en "om vir sover die ander ampspligte dit toelaat, Woord en sakrament te bedien." ${ }^{\prime \prime 6}$ In Bepaling 80 word in die besonder melding gemaak van hulle verantwoordelikheid met betrekking tot die bevordering van die teologiese wetenskap. ${ }^{97}$ In Bepaling 81 word hulle preadvies met betrekking tot belydenis en liturgie nader omskryf. ${ }^{98}$

Van die vroegste tye af het die gereformeerde kerkreg die amp van teologiese professor geken by name van die doctores. ${ }^{99}$ Die differensiasie van dienaar van die Woord in die gestalte van herder, leraar en professor dateer reeds uit die dae van die reformasie. Volgens die Konvent van Wezel (1568) het die teologiese professor hoofsaaklik dieselfde dienswerk verrig as die herders en leraars. ${ }^{100}$ Sedert die 
Sinode van Gravenhage (1586) word die amp van doctor egter beskryf as 'n volledige selfstandige bediening. ${ }^{101}$ Sy "diakonia" is in die besonder "de Heilige Schriftuur uit te leggen, en de zuivere leer tegen de ketterijen en dolingen voor te staan." 102

Prinsipieel is daar geen beswaar dat die teologiese professor en dosent in die teologie bedienaar van die Woord in die volle sin van die woord mag wees nie. Prakties sal seker altyd onthou moet word dat sy primêre taak die opleiding van toekomstige predikante en die bevordering van die teologiese wetenskap is. Tot die gewone "diakonia" van die predikant sal hy daarom altyd alleen toegelaat word so ver as sy primêre taak dit toelaat. In die huidige tydsgewrig skyn dit feitlik onmoontlik om tegelyk aan beide reg te laat geskied. Indien daar egter teologiese professore en dosente in die teologie is wat die "charisma" ontvang het om aan beide reg te laat geskied, sal die praktiese oorweging nooit die prinsipiële kan oorwin nie. In die lig van die breë "diakonia" wat die "episkopos"/"presbuteros" in die Nuwe Testament verrig het, is dit ook nie prinsipieel foutief om die professor en teologiese dosent toe te laat tot die amp van ouderling oor die hele linie nie. Net soos die gewone bedienaar van die Woord kan sy "diakonia" tegelyk bediening van die Woord en opsighoudend van aard wees.

Die "diakonia" van die gewone dienaars van die Woord word in die Nederlandse Geloofsbelydenis omskryf as die spreek van God se Woord, die bediening van die sakramente en om saam met die opsieners en diakens as Raad van die kerk te fungeer. ${ }^{103}$ Die gereformeerde kerkreg sien die opdrag meer gedifferensieerd: Dit voeg die bediening van die gebede en besondere opsig oor die ouderlinge en diakens by. ${ }^{104}$ Die bevestigingsformulier vir dienaars van die Woord omskryf die funksie in breë trekke as bediening van Woord en sakramente, die daarby behorende gebede en die opsig. Met betrekking tot die verkondiging van die Woord bestaan daar differensiasie in die sin van verkondiging in die algemeen en in die besonder. Differensiasie weer wat laasgenoemde betref in die sin van onderrig, vertroos en vermaan. ${ }^{105}$ Die Kerkwet van die Nederduitsch Hervormde kerk van Afrika omskryf in breë trekke die "diakonia" van die predikant in dieselfde terme en van dieselfde omvang as die bevestigingsformulier. Prominent word egter bygevoeg die kategese en die bearbeiding van hulle wat van die evangelie vervreemd is. ${ }^{106}$ Beide die Nederlandse Geloofsbelydenis en die bevestigingsformulier omskryf hierdie "diakonia" hoofsaaklik as 'n binne gemeentelike aktiwiteit. Net sydelings word in die bevestigingsformulier melding gemaak van die bediening van die evangelie aan die heidene. Selfs die Kerkwet, wat die "diakonia" van die predikant breed omskryf, laat nie voldoende ruimte vir die verkondiging van die evangelie aan die heidene nie. Indirek kan dit miskien afgelei word van die breë 
omskrywing "Verkondiging van die Woord van God"107 en die bearbeiding van hulle wat van die evangelie vervreemd is ${ }^{108}$ Hier is ' $n$ duidelike klemplasing op die binnegemeentelike arbeid bo die verkondiging aan hulle wat nog buite is nie. Die omgekeerde volgorde ken die Skrif ook nie. Hierdie klemplasing het daartoe gelei dat daar vandag nie veel teregkom van die kerk se "evangelisasie"-arbeid nie. ${ }^{110}$ Met betrekking tot die bediening van die Woord aan die swartmense kom daar wel iets tereg ${ }^{111}$ maar met betrekking tot die blankes feitlik niks nie.

Moet ons gemeentes nie almal die helfte kleiner wees, sodat die predikant ook sy aandag aan hierdie werk kan gee nie? Moet ons nie miskien in plaas van net een 'n hele paar predikante vir hierdie werk afsonder nie? Of het die tyd nie miskien ryp geword dat ons weer die amp van evangelis in die kerk terug kry nie? Wat hierdie evangeliste betref, weer verdere differensiasie - evangeliste vir die immigrante, die Jode, die Engelse, die sektariërs, ens. Die kerk het reeds in beginsel besluit dat daar nie afsonderlike gemeentes vir hierdie groepe gevorm gaan word nie. Hiermee is indirek besluit dat al die predikante hierdie werk moet doen. Hierdie besluit het daartoe gelei dat daar prakties gesproke niks van hierdie werk tereg kom nie. Ander bevolkingsgroepe het nie ' $n$ ander evangelie as ons nodig nie, ook nie ' $n$ ander wyse van bearbeiding nie. Die taal- en ander agtergronds faktore lei egter daartoe dat hierdie mense nie deur die gewone predikant bereik word nie.

In beginsel het die Kerk reeds aanvaar dat sekere predikante afgesonder word met die oog op besondere werkterreine. ${ }^{112}$ Prinsipieel kan daar geen beswaar teen ingebring word nie. Die vraag moet egter gevra word of daar in die huidige tydsgewrig nie behoefte is om meer predikante met die oog op besondere dienswerk binne 'n bepaalde groep af te sonder nie. Die behoefte bestaan wel en sal bly bestaan solank as wat ons gemeentes van die huidige omvang is.

Uitbreiding van hierdie amp na die vrou vra ook ons aandag. As daar vrouelidmate is met 'n besondere "charisma" wat betref Woordverkondiging en hierdie "charisma" is met inhoud gevul deur studie, sal die kerk prinsipieel die betrokkenes nie kan wegwys nie.

Die vraag na die predikant se funksionering as ouderling in die plaaslike gemeente en in breër verband, was in die verlede dikwels die voorwerp van diskussie. Volgens die Nuwe Testamentiese gegewens en die bevestigingsformulier is daar niks wat dit verbied nie. 'n Predikant wat in die kerk funksioneer as ' $n$ ouderling is myns insiens juis die uitlewing van die Nuwe Testamentiese "presbuteros"/"episkopos" gestalte.

Die huidige stelsel van tydelik-deeltydse predikante is in die verlede wyd bespreek. ${ }^{113}$ Sonder enige twyfel is hierdie stelsel seker in stryd met die reformatoriese kerkreg soos prof A D Pont aangetoon 
het. Vanuit die Skrif kan daar egter niks negatiefs teen hierdie beginsel ingebring word nie.

Andersyds kan dit ook nie gefundeer word as juis 'n besondere wyse waarop die kerk in die wêreld moét fungeer nie. Die praktiese besware wat deur prof A D Pont na vore gebring is, is egter voldoende om die kerk te laat afsien van hierdie werkwyse. ${ }^{114}$ As alles bymekaar getel word, blyk dit dat die aanbeveling van proffe $\mathrm{J} P$ Oberholzer, B J Engelbrecht en P S Dreyer wat voor die 1973 Algemene Kerkvergadering gedien het, die koers behoort te wees wat die kerk behoort te gaan in hierdie verband: "Ons beveel aan dat hier uitgesluit word alle persone wat die dienswerk in die kerk verlaat het ter wille van die bekleding van ampte waarvoor die opleiding van die kerk hulle nie toegerus het nie en wat met die werk van die kerk niks te make het nie. In aanmerking sal dan alleen kom dié persone wat vanweë hulle opleiding as predikante doseerwerk aan universiteite doen, en wat spesifiek met die voorbereiding van studente vir die opleiding as dienaars van die Woord te doen het ... Die volgende persone sal dan in aanmerking geneem word: (1) Dosente aan die Universiteit van Pretoria wat die teologiese opleiding deurloop het en dosente is in die vakke wat deur die kerk voorgeskryf word of wat deur die kerk goedgekeur word, met die oog op toelating tot die BD studie; (2) Dosente aan Swart-universiteite wat verbonde is aan die Teologiese Fakulteite, indien predikante vir die Bantoe Hervormde Kerk daar opgelei word, en dosente aan Swart-universiteite wat vakke doseer wat deur die kerk voorgeskryf word vir die voorstudie tot die teologie." 115 Prinsipieel skyn dit korrek te wees dat alle predikante wat voltyds met die dosering en bestudering van die teologie besig is, ook tot hierdie kategorie gereken sal word.

Die amp van die ouderling word in die Nederlandse Geloofsbelydenis omskryf as ' $n$ raad wat saam met die predikante en diakens dien om die ware godsdiens te onderhou en te sorg dat die ware leer sy loop het. ${ }^{116}$ Dit lyk of die funksionering hier gesien word as beperk tot die "raad". Volgens die bevestigingsformulier is die ouderlinge saam met die dienaars van die Woord mederegeerders. Hulle moet opsig hou of elkeen in belydenis en wandel hom behoorlik gedra en selfs opsig hou oor die leer en die lewe van die bedienaars van die Woord. ${ }^{117}$ Op die Konvent van Wezel is die ouderling se werk hoofsaaklik beskryf as opsighou oor sy eie huis en wyk. ${ }^{118}$ Die Sinode van Dordt 1574 roep die ouderlinge op om ook die siekes te besoek en te vertroos. Daar word in die besonder melding gemaak dat hulle nie opsig hou oor die dienaars van die Woord nie. Een ouderling kan afgesonder word vir notulering. ${ }^{119}$ Sedert Middelburg 1581 hou hulle opsig oor die dienaars van die Woord. ${ }^{120}$ By die Nasionale Sinode te Dordt 1618-1619 word aan hulle opgedra "ook anderen tot de Christelike religie te vermanen."121 Dit is waarskynlik 'n opdrag met 
betrekking tot die heidene. Die artikels van Wezel 1568 ontsê die ouderlinge alle beheer oor kerklike goedere. ${ }^{123}$

Behalwe bogenoemde "diakonia" dra die Kerkwet ook nog die kategese, die diens van die gebede en toesig oor die kerklike goedere aan hulle op. ${ }^{123}$ Opsommend kan gesê word die ouderlinge se funksie is hoofsaaklik regering en opsig wat gedoen word vanuit die Woord.

In die praktyk het daar reeds wye differensiasie ontstaan met betrekking tot die "diakonia" van die ouderlinge. Ouderlinge word afgesonder vir jeugwerk, kategese, notulering en immigrantebearbeiding. Moet hierdie differensiasie nie nog verder deurgevoer word nie? Feitlik in elke gemeente is daar ouderlinge met ' $n$ besondere "charisma" met betrekking tot een of ander element wat val onder die opsig. Die een ouderling het die "charisma" om te praat met drankverslaafdes, die ander een met siekes, die ander een met heidene, die ander een met ontugtiges en ' $n$ ander een miskien met die onbarmhartiges. Moet hierdie "charisma" nie verder uitgebou word deur besondere toerusting en hierdie oudstes dan in die besonder vir hierdie dienswerk afgesonder word nie?

Net soos die vraag na deeltydse predikante onder bespreking is, so ook die vraag na voltydse ouderlinge met honorering. Blykens $1 \mathrm{Ti}-$ moteus 5:17 was die "timès" ook bestem vir die regerende ouderling. In feitlik elke gemeente is daar een of twee gepensioneerde ouderlinge met ' $n$ besondere "charisma" wat die ouderlingswerk betref. Die voltydse diens van een of twee sulke ouderlinge kan vir 'n gemeente van oneindige waarde wees.

Met betrekking tot die vrou as ouderling sal ons waarskynlik dieselfde pad moet bewandel as wat gesê is by die predikante. Het die vrou in die kerk nie reeds ten volle deel gekry aan die regering toe sy as diakones met sitting op die kerkraad toegelaat is nie?

Volgens die Nederlandse Geloofsbelydenis word aan die diakens opgedra om die armes en bedruktes te help en te troos. ${ }^{124}$ Hierdie omskrywing wys in die rigting van geestelike en materiële hulp. Die Nederlandse Geloofsbelydenis gee aan die diakens sitting op die kerkraad en sodoende het hulle ook deel aan die regering. Die algemene reformatoriese opvatting met betrekking tot die diakensamp word op die Sinode van Dordt volledig beskryf. In hooftrekke bestaan dit uit insameling en uitdeling van materiële middele en vertroostinge uit die Woord van God. ${ }^{125}$ Die huidige bevestigingsformulier beskryf die diakensamp in dieselfde hooftrekke. Die aantal diakens en die bestaan van hierdie amp word telkens beskryf in terme wat bepaal word volgens die plaaslike omstandighede. Selfs Calvyn is van oordeel dat daar tye kan kom dat hierdie amp nie nodig sal wees nie. ${ }^{126}$ Op die Konvent van Wezel word bepaal dat daar drie groepe diakens moet wees. Die een groep besoek mense wat in nood verkeer wat nie van materiële aard is nie. Die tweede groep samel 
offergawes in en deel dit uit aan die behoeftiges. Die derdegroep samel offergawes in wat nodig is vir die instandhouding van die erediens. ${ }^{127}$ Volgens die sinodebesluit is daar telkens in die lig van die plaaslike omstandighede besluit of daar diakonesse moet wees of nie. ${ }^{128}$

'n Wye differensiasie binne die amp van diaken word vandag nie aangetref nie. In praktyk bestaan daar vandag net een groep diakens met die breë funksie soos hierbo beskryf. Prakties kom daar dikwels net van die insameling in die diakenswerk iets tereg. In die meeste gemeentes is die getal van die diakens vandag net so groot of groter as die van die ouderlinge. 'n Vakature met betrekking tot die diakenamp wek dikwels meer kommer as 'n wyk sonder 'n ouderling. Is die omstandighede vandag sodanig dat daar met so 'n groot getal diakens gewerk moet word? Is die indeling van die diakens in verskillende groepe, soos ons dit aantref op die Konvent van Wezel, nie vandag ook gewens nie? Een of twee diakens vir die versorging van die armes - een of twee vir die versorging van die siekes - een of twee vir die versorging van die wese en die weduwees en ' $n$ paar wat omsien na die behoeftiges. Is dit nie ook nodig dat diakens met 'n besondere "charisma" in hierdie verband, verder toegerus sal word nie? Wat die insameling betref, ken die Skrif twee werkwyses: die self bring ${ }^{129}$ en die gaan haal. ${ }^{130}$ Kan deur die gebruik van moderne tegnieke die "insamelende" diakens nie beperk word tot vyf of ses nie? Die wins wat sodoende behaal word op die getal van diakens kan met baie groter vrug gevoeg word by die getal van die ouderlinge.

Vandag het dit reeds praktyk geword dat die kerk hom bedien van sekere hulporgane. Die bestaan van hierdie hulporgane word bevraagteken met die stelling dat alle werk in die gemeente verrig moet word deur die ampte. Prinsipieel is dit korrek dat die leiding altyd sal moet uitgaan van die ampte, maar dit is tog volkome Skriftuurlik dat daar in die gemeente "charismata" sal wees wat nie noodwendig gebonde is aan die ampte nie.

Alle "diakonia" van die ampsdraers geskied met die oog op die uiteindelike "diakonia" van die gewone lidmate. ${ }^{131}$ In die bespreking van die ampte sal hierdie aspek ook voortdurend in die oog gehou moet word. 
$1 \mathrm{H}$ Berkhof, Wat is er aan de hand met het ambt, studierapport over het ambt, aangeboden door de generale synode van de Nederlandse Hervormde Kerk, krachtens besluit van haar vergadering van 18 Februarie 1969, Boekencentrum N V's Gravenhage 1971.

2 Die Praktiese Teologiese Werkgemeenskap besin tydens twee kongresse oor die ampte - Studieresultate in Die Kerk se Werk, Kongresreferate van die Werkgemeenskap vir Praktiese Teologie 1974-1975. Die Nuwe Testamentiese Werkgemeenskap maak die ampte in die Pauliniese briewe tot besondere voorwerp van studie gedurende 1976 . Verskeie uitgawes van die Ned. Geref. Teologiese Tydskrif dek hierdie onderwerp sedert 1970. Die ampte is ook telkens aan die orde in Theologia Evangelica, Tydskrif van die Fakulteit Teologie, Universiteit van SuidAfrika. Die Hervormde Teologiese Studies vir die bevordering van die Bybels-Reformatoriese Teologie in Suid-Afrika laat die onderwerp nie onbespreek nie. In die Skriflig. tydskrif van die Gereformeerde Teologiese Vereniging, bring die ampte telkens in diskussie.

3 Notule van die Ses en vyftigste Algemene Kerkvergadering bladsy 38.

4 Vergelyk L Floor, Die Presbiter by Lukas en Paulus, Theologia Evangelica, aw, Jaargang VII nommer 2, bl 83-88. Sien ook G P L van der Linde, Die Grondbeginsels van die Presbiteriale Kerkregeringstelsel, Pro Rege-Pers Beperk Potchefstroom 1965, bl 2832 en A F N Lekkerkerker, Oorsprong en funktie van het ambt, Boekencentrum N V S' Gravenhage 1971, bl 88-96.

$5 \mathrm{Vgl} \mathrm{H}$ A Lombard, Charisma-Amp, Die Kerk se Werk, aw, bl. 48; H Ridderbos, Paulus, ontwerp van zijn Theologie, J H Kok N V Kampen 1966, bl 534 en H A Lombard, Charisma and Church Office, referaat tydens Nuwe Testamentiese Werkgemeenskap vergadering 1976, ongepubliseerd.

6 Nederlandse Geloofsbelydenis, Kerkboek Nederduitsch Hervormde Kerk van Afrika, artikel 30, bl 21.

7 Formulier om die dienaars van die Goddelike Woord te bevestig, Kerkboek, aw, bl 168.

$8 \mathrm{Vgl}$ Formulier vir die bevestiging van ouderlinge en diakens, Kerkboek, aw, bl 168.

9 A D R Polman, Onze Nederlandsche Geloofsbelijdenis, verklaard uit het verlede, geconfrontreerd met het heden, T Wever-Francher, deel 4, bl 8-12.

10 A D R Polman, aw, bl 8.

11 Johannes Calvijn, Institutie, of onderwijzing in de christelijke godsdienst, Uit het Latijn vertaald door A. Sizoo, Derde Deel bevattende Boek IV, Naamlose Vennootschap W D Meinema-Delft derde druk, bl 58.

$12 \mathrm{Vgl}$ L Goumaz, Het ambt bij Calvijn - een samenvatting naar zijn commentaren op het Nieuwe Testament, Vertaald en ingeleid deur K. Deddens, T. Wever-Franeker 1948, bl 18.

$13 \mathrm{Vgl} \mathrm{G} \mathrm{H} \mathrm{Kersten,} \mathrm{Kerklijk} \mathrm{Handboekje,} \mathrm{Opnieuw} \mathrm{uitgegeven} \mathrm{op} \mathrm{last} \mathrm{van} \mathrm{de} \mathrm{Generale}$ Synode der Gereformeerde Gemeenten in Nederland; De Banier - Utrecht Tweede druk 1961.

$14 \mathrm{Vgl} \mathrm{J} \mathrm{L} \mathrm{de} \mathrm{Villiers,} \mathrm{Indications} \mathrm{of} \mathrm{Church} \mathrm{Rule} \mathrm{or} \mathrm{Government} \mathrm{in} \mathrm{Pauline} \mathrm{Paranetic}$ Material, Referaat Nuwe Testamentiese Werkgemeenskap van Suid-Afrika 1876, ongepubliseerd.

15 Vgl FJ van Zyl, Die Wese en doel van die Ampte, Die Kerk se Werk, aw, bl 18.

16 Vgl Johannes 16:14.

17 Vgl J Calvijn, aw bl 54.

18 Alan Richardson, An Introduction to the Theology of te New Testament, Bloomsbury Street, London 1958, bl 312-329.

19 Vgl Handeling 1-6.

$20 \mathrm{Vgl} \mathrm{A}$ A van Ruler, Bijzonder en Algemene Ambt, C F Callenbach-Nijkerk 1952, bl 27; P H J Huiser, De ouderling en de Prediking. J H Kok N V Kampen 1959, bl 19; K Dijk, Handboek voor de Ouderling, Van Keulen-Delft 1952, bl 9; G P van Itterzon, Het Kerkelijk ambt in geding, J H Kok Kampen 1974, bl 27.

$21 \mathrm{Vgl}$ Formulier vir de bevestiging van ouderlinge en diakens, Kerkboek, aw bl 171; Johannes Calvijn, De Handelingen der Apostelen, opnieuwuit het Latijn vertaald, naar de editie van Baum, Cunits en Reuss door ds G Wielenga, W A de Groot Goudiraan 1970, Eerste deel, bl 202; Walter Luthi, Die Apostelgeschichte ausgelegt für 
die Gemeinde, Basel 1958, bl 109. Werner de Boor, Die Apostelgeschichte, R Brockhaus verlag Wuppertal 1965, bl 130. B Spoelstra, Is die "Ouderlingamp" in Hand 6 ingestel? In die Skriflig, aw, bl 52.

22 G Stählin, Die Apostelgeschichte, soos aangehaal L Floor, Die Presbiter by Lukas en Paulus, Theologia Evangelica, aw, Jaargang 7 no 2, bl 89.

23 F F Bruce, The Acts of the Apostles, The Tyndale Press 1951, bl 152; E Haenchen, Apostelgeschichte, Meyers Kommentar, Vandenhoeck und Ruprecht 1861, bl 219; A $\checkmark$ Ginkel, De Ouderling, Oorspronglen Ontwikkeling van het ambt van ouderling en de Functiek daarvan in de Gereformeerde Kerk der Nederlanden in de 16e en 17e eeuw, Ton Bolland 1975, bl 23. L Floor, Die Presbiter by Lukas en Paulus, In die Skriflig, aw, Maart 1976, bl 22.

24 L Floor, Theologia Evangelica, aw, bl 90.

25 A v Ginkel, aw, bl 23.

26 J C Coetzee, Enkele Skrifgegewens oor die diakenamp, In die Skriflig, aw, 1976 no 4, bl 48.

27 Handelinge 11:30

28 Handelinge 15 en 21

29 Handelinge $16: 4$

301 Petrus 5:2

31 A v Ginkel aw, bl 25

32 A v Ginkel, aw, bl 26.

33 A v Ginkel, aw, bl 27.

34 1 Petrus 5:1.

35 E Haenchen, aw, bl 593.

36 A F N Lekkerkerker, Oorsprong en funksie van het ambt, 1971, bl 118.

37 J H Roberts, Die opbou van die kerk volgens die Efese-brief, 1963, bl 151-156.

38 F W Grosheide, Die Handelingen der Apostelen 11, Kommentaar op het Nieuwe Testament, H A von Bottenburg N V 1948, bl 244; J de Swaan, De Handelingen der Apostelen, Tekst en Uitleg, J B Wolters, Groningen, den Haag 1920, bl 135; C S Williams, The Acts of the Apostles, Blacks New Testament Commentaries, Adam and Charles Black 1957, bl 232 en kommentare op Handelinge soos vermeld by 21 en 23.

39 Handelinge 20:20.

40 A v Ginkel, aw, bl 36.

41 J Calvijn, Commentaries on the Epistles of Paul to the Galatians and Ephesians, translated from Latin by W Pringle, M B Eerdmans 1948, bl 278.

42 J Calvijn, Kommentaar op Efesiers, aw, bl 279.

43 F Reinecker, Der Brief des Paulus an die Epheser, Wuppertaler Studienbibel, R Brokhaus 1968, bl 145 .

44 Bevestigingsformulier vir Ouderlinge en Diakens, Kerkboek, aw, bl 169; Vergelyk ook L G Zwanenburg, Leer, ambt en leven Paulus brieven aan Timotheus, Ton Bolland 1971, bl 110. W Hendriksen, A commentary on the Epistles to Timothy and Titus, The Banner of Truth Trust, bl 180 en J Calvijn, De Pastorale Brieven, vertaald uit het Latijn door H Schroten, J H Kok N V Kampen 1966, bl 119.

45 E L Smelik, De Brieven van Paulus aan Timotheüs, Titus en Filemon, De Prediking van het Nieuwe Testamet, Callenbach-Nijkerk 1961, bl 76; en R C H Lenski, The Interpretation of St. Paul's Epistles to the Colossians, to the Thessalonians, to Timothy, to Titus and to Philemon, Augsburg Publishing House 1937, bl 679.

46 A v Ginkel, aw bl 38.

47 Vgl H Ridderbos, De Pastorale Brieven, Commentaar op het Nieuwe Testament, J H Kok Kampen 1967, bl 138.

48 Die Kommentare vermeld by 44,45 en 47 is dit eens dat die "times" eer beteken, maar in die besonder verwys na lewensonderhoud.

$491 \operatorname{Tim} 3: 2$.

$501 \operatorname{Tim} 3: 5$.

51 Titus 1:10.

$521 \operatorname{Tim}$ 5:17 en $1 \operatorname{Tim}$ 3:2.

$53 \mathrm{Vgl} \mathrm{Christus} \mathrm{se} \mathrm{opdrag} \mathrm{aan} \mathrm{die} \mathrm{Kerk,} \mathrm{Matt} \mathrm{28:19.}$

$54 \mathrm{Vgl}$ oa die spreek in tale in 1 Kor 14.

55 A J Bronkhorst, Schrift en Kerkorde, Een bijdrage tothet onerzoek naar de mogelijkheid van een Schriftuurlijke Kerkorde, N.V. Zuid-Holl Den Haag 1947, bl 108. 
$56 \mathrm{Vgl} 1$ Timotheus 3:8-10.

57 Vgl Beyer se verklaring van "diakonia" in G H Kittel, Theological Dictionary of the New Testament, Translated by G D Bromiley, Wm B Eerdmans 1964, Volume 11, bl 87.

58 J Calvijn, Institutie, aw, bl 64 .

$59 \mathrm{Vgl} \mathrm{Notule} \mathrm{Algemene} \mathrm{Kerkvergadering} 1973$.

$60 \mathrm{~F}$ W Grosheide, De Eerste Brief aan de kerk te Korinthe, Commentaar op het Nieuwe Testament, J H Kok Kampen, 1957, bl 378.

61 F Davidson, The New Bible Commentary, London the Inter- Varsity Fellowship 1953, bl 987.

62 G M M Pelser, Women and Ecclesiastical Ministers in Paul, referaat gelewer by Nuwe Testamentiese Werkgemeenskap van SA 1976, ongepubliseerd, bl 18-22.

63 Vgl G M M Pelser, aw, bl 16.

64 Heinz-Dietrich Wendland, Die Briefe an die Korinther, Das Neue Testament Deutsch, Göttingen - Vandenhoeck und Ruprecht 1968, bl 132.

65 F J Pop, Die Eerste Brief van Paulus aan die Corinthiërs, De Prediking van het Nieuwe Testament, G F Callenbach N V - Nijkerk 1965, bl 338. Vgl. ook R. Jamieson, A Commentary Critical Experimental and Practical on the Old and New Testament, Wm B Eerdmans 1945, bl 326.

66 E P Groenewald, Die Eerste Briefaan die Korinthiërs, N G Kerk-Uitgewers Kaapstad Pretoria 1967, bl 139.

67 Gerh Huls, De Dienst der Vrouw in de Kerk, een onderzoek naar de plaats der Vrouw in een presbyteriale Kerkorde, H Veenman en Zonen 1951, bl 44.

68 F W Grosheide, Kommentaar op 1 Korintiërs, aw, bl 293, Vgl ook A Robertson en A Plummer, A Critical and Exegetical Commentary on the First Epistle of St Paul to the Corinthians, The International Critical Commentary, $T$ and $T$ Clark Edinburgh 1911, bl 230.

69 B Gemser (redakteur), Die Bybel met Verklarende aantekeninge, Deel 111, Verenigde Protestantse Uitgewers Kaapstad 1957, bl 474.

70 G M M Pelser, aw, bl 9.

71 J Calvijn, Kommentaar op 1 Timotheus, aw, bl 59.

72 H Ridderbos, Pastorale Brieven, aw bl 81 en 82.

73 B Gemser (redakteur), Die Bybel met verklarende aantekeninge, aw, bl 610.

74 W Hendriksen, aw bl 109.

75 L G Zwanenburg, aw bl 56.

76 The Interpreters Bible, Volume 11, aw bl 405.

77 G M M Pelser, aw, bl 25

78 Otto Weber, Karl Baths Kirchliche Dogmatik, Ein einführender Bericht zu den Bänden 1, bis 1V 2, Neukirchen Kreis Moers 1958, bl 278.

$79 \mathrm{Vgl} 2$ Kor 1:24.

801 Petrus 5:3.

81 Rom 12:8, 1 Tess. 5:12, en 1 Tim. 5:17.

821 Kor 12:28.

83 Hand 5:22, Hebr 13:7, 17 en 24.

84 Hand 20:28, Ef 4:11 en 1 Pet 5:2.

85 Hand 20:28, Filip 1:1 1 Tim 3:2 en Titus 1:7.

86 Gerh Huls, aw, bl 179.

87 R Boon, Apostolisch ambt en reformatie, Nijkerk 1965.

88 A v Ginkel, aw, bl 300.

89 H d'Espine, Les Anciens, conducteurs de l'eglise, soos aangehaal A v Ginkel, aw, bl 301.

90 H Berkhof, aw.

91 A v Ginkel aw, bl 304-312.

92 Kerkwet van die Nederduitsch Hervormde Kerk van Afrika met wysigings soos aangeneem tot en met die 57ste Algemene Kerkvergadering, artikel 5, 1, bl 2.

93 Kerkwet, aw Artikel 5,2, bl 2.

94 Kerkwet aw, Bepaling 163, 1 en 2 bl 90.

95 Kerkwet aw, Bepaling 78 bl 51.

96 Kerkwet aw, Bepaling 78, d en e bl 52 . 
97 Kerkwet aw, Bepaling 80 bl. 52 .

98 Kerkwet aw, Bepaling 81 bl. 52.

$100 \mathrm{G}$ H Kersten, aw, artikelen van Wezel, artikel 14, bl 17.

$101 \mathrm{G}$ H Kersten, aw, artikel 2, 1155 en artikel 3, bl 177.

102 G H Kersten aw, artikel 18, bl 180.

103 Nederlandse Geloofsbelydenis, Kerkboek, aw, artikel 30, bl 21.

104 G H Kersten, aw, artikel 8, bl 124.

105 Formulier om die dienaars van die Goddelike Woord te bevestig, Kerkboek, aw, bl 160.

106 Kerkwet, aw, Artikel 5 bl 2.

107 Kerkwet, aw, Artikel 5, 3(a), bl 2.

108 Kerkwet, aw, Artikel 5, 3(k), bl 3.

$109 \mathrm{Vgl}$ oa Mattheus 28:19.

$110 \mathrm{Vg}$ RIngsverslae van die Nederduitsch Hervormde Kerk van Afrika.

111 Vgl Ringsverslae van die Nederduitsch Hervormde Kerk van Afrika.

112 Tans het die Nederduitsch Hervormde Kerk van Afrika predikanteafgesonder virhospitaalbearbeiding, ouetehuise, sendingwerk en Bybelverspreiding.

$113 \mathrm{Vgl}$ Notule van die Ses-en-vygtigste AlgemeneKerkvergadering van diek Nederduitsch Hervormde Kerk van Afrika, bl 38 en A D Pont, tydelik. Deeltydse predikante, H T S Studia Theologica Varia S P J J van Rensburg, bl 97.

114 A D Pont, aw, bl 108 en 116.

115 Agenda met Bylaes vir die Ses en vyftigste Algemene Kerkvergadering van die Nederduitsch hervormde Kerk van Afrika, Bylae VL.

116 Nederlandse Geloofsbelydenis, artkel 30, Kerkboek, aw, bl 21.

117 Formulier vir die bevestiging van ouderlinge en diakens, Kerkboek, aw, bl 168.

118 G H Kersten, aw, artikel 8, bl 25.

119 G H Kersten, aw, artikel 9, bl 25.

$120 \mathrm{G} \mathrm{H}$ Kersten, aw, artikel 16, bl 126 en artikel 21, bl 159.

121 G H Kersten, aw, artikel 23, bl 181.

122 G H Kersten, aw, artikel 16, bl 29.

123 Kerkwet, aw, artikel 4, bl 3.

124 Nederlandse Geloofsbelydenis artikel 30, Kerkboek, aw, bl 21.

125 G H Kersten, aw, artikel 25, bl 182.

126 L Goumaz, aw, bl 26.

127 G H Kersten, aw, artikel 12, bl 28.

128 G H Kersten, aw, artikel 10, bl 28 en artikel 56, bl 145.

$129 \mathrm{Vgl} \mathrm{Maleagi} \mathrm{3:10} \mathrm{en} \mathrm{Hand} \mathrm{4:34.}$

$130 \mathrm{Vgl} 1$ Kor 16:2 en 3.

$131 \mathrm{Vgl} \mathrm{H}$. Kraemer, Het vergeten Ambt in de Kerk, Boekencentrum N V-'S Gravenhage 1960. 